\title{
Order through the Gaze: A Comparative Perspective of the Construction of Visibility in Monitorial Schooling \\ (German States - Spain, approx. 1815-1848)
}

\author{
Orden aTravés de la Mirada: Una Perspectiva \\ Comparada de la Construcción \\ de la Visibilidad en las Escuelas Mutuas \\ (Estados Alemanes - España, ca. 1815-1848)
}

\author{
L'Ordre par le Regard : Une Perspective \\ Comparative de la Construction de la Visibilité \\ dans l'Enseignement Mutuel (États de \\ l'Allemagne - de I'Espagne, approx. 1815-1848)
}

\section{Marcelo Caruso}

Humboldt University (Berlin) ${ }^{1}$

\section{ABSTRACT}

Visibility of bodies and actions in the classroom is a major feature of modern schooling as a disciplinary institution. The mere fact that children attended elementary schools in early modern times did not mean that effective work took place. Old techniques of schooling were challenged by new proposals at the beginning of the nineteenth century. Among them, monitorial schooling represented a crucial movement towards an increased standardisation of educational practices and institutions. This British model of schooling was based on a strict routine in the classroom, carried out by numerous children in the role of helpers, also called monitors. In this system of teaching, a hierarchical structure of monitors guaranteed continuous activity of a well-ordered mass of pupils. The worldwide spread of monitorial schooling was a first attempt to extend a disciplined daily life into the classrooms before group teaching techniques took the forefront. Evidently, the challenge of teaching 200-300 pupils in a room made demands on control and surveillance, in order to interrupt possible alliances between children. This 
contribution describes different versions of the control of large groups of children through visibility in German and Spanish schools. In both contexts, educationalists and schoolteachers reformed many aspects of the "British" system, which foresaw "pyramidal" structure of gazes. In the German states, a general concern about the position of the teacher arose. Germans criticised the teaching role of monitors and reinforced the role of the adult's gaze in ordering the classroom. In the Spanish case, educationists started copying the English original, but they later reinforced the stability of authority by giving a more substantive role to the "intermediate" gazes of the general monitors. Both developments are traced back to prevailing notions of teaching in each context. The different paths of reception and interpretation of this highly codified system of teaching display the existence of different "cultures of discipline."

Key words: classroom, discipline, visibility, authority, Spain, Germany.

\section{RESUMEN}

La visibilidad de cuerpos y acciones en las aulas es una de las características centrales de escolaridad moderna como institución disciplinaria. El hecho de que los niños vayan a una escuela elemental no significa en los tiempos de la modernidad temprana que allí tuviera lugar un trabajo efectivo. Viejas técnicas de enseñanza fueron cuestionadas por nuevos modelos hacia el comienzo del siglo XIX. Entre ellos, el sistema de enseñanza mutua representó un momento crucial en torno a una estandarización creciente de las instituciones y prácticas educativas. Este modelo inglés de enseñanza se basaba en una rutina estricta en el aula que era garantizada a través del uso de niños como ayudantes, los monitores. En este sistema de enseñanza, la estructura jerárquica de monitores garantizaba una actividad continua y un ordenamiento apropiado de la masa de alumnos. La expansión mundial de este sistema fue el primer intento de extender una cotidianeidad disciplinaria en las aulas antes del triunfo de las técnicas de enseñanza grupal. Evidentemente, el desafío de enseñar 200 a 300 niños en un aula acrecentó las demandas de control y supervisión con el objeto de interrumpir alianzas posibles entre los niños. Este artículo describe las diferentes versiones de control de grandes grupos de niños a través de técnicas de visibilización en las escuelas mutuas españolas y alemanas. En ambos contextos, educadores y maestros reformaron varios aspectos del "sistema británico" que preveía una estructura piramidal de las miradas. En los estados alemanes, una preocupación general sobre la posición del docente adulto predominó en la discusión. Los alemanes criticaron el rol de los mnitores y reforzaron el rol de la mirada del adulto en el ordenamiento del aula. En el caso español, los educadores comenzaron por copiar el modelo inglés, pero más tarde reforzaron las miradas "intermediarias" de los monitores generales. Ambos desarrollos son explicados a través de las nociones predominantes de la enseñanza en cada contexto. Los diversos senderos de recepción e interpretación de este sistemat de enseñanza altamente codificado pone en evidencia la existencia de diversas "culturas de la disciplina."

Descriptores: sala de clase, disciplina, visibilidad, autoridad, España, Alemania.

\section{RÉSUMÉ}

La visibilité corporelle et celle des actions dans la salle de classe est un aspect majeur de l'instruction moderne comme institution disciplinaire. Le simple fait que les enfants aient fréquenté les écoles élémentaires aux débuts des temps modernes ne signifiait pas qu'un travail efficace y avait eu lieu. Les anciennes techniques d'instruction furent contestées par de nouvelles propositions au début du $19^{\mathrm{e}}$ siècle. Entre autres, l'instruction mutuelle représentait un mouvement crucial vers une standardisation accrue des pratiques et des institutions éducatives. Ce modèle britannique d'instruction était basé sur une routine rigide dans la salle de classe, effectuée par de nombreux enfants dans le rôle d'auxiliaires, aussi appelés moniteurs. Dans ce système d'enseignement, une structure hiérarchique de moniteurs assurait l'activité ininterrompue d'un grand nombre d'élèves. La dissémination mondiale de l'enseignement mutuel fut une première tentative pour étendre une vie quotidienne disciplinée dans les salles de classe avant que les techniques d'enseignement de groupe n'aient pris le premier rang. Évidemment, 
le défi d'enseigner à 200-300 élèves dans une seule salle exigeait du contrôle et de la surveillance, pour prévenir les alliances possibles entre enfants. Ce papier décrit différentes versions du contrôle de grands groupes d'enfants par la visibilité dans les écoles allemandes et espagnoles. Dans les deux contextes, les éducateurs et les enseignants ont réformé plusieurs aspects du système " britannique " qui prévoyait une structure " pyramidale » du regard (la surveillance). Dans les états germaniques, un souci général au sujet de la position de l'enseignant surgit. Les Allemands critiquèrent le rôle pédagogique des moniteurs et renforcèrent celui du " regard fixe " de l'adulte pour ordonner la classe. Dans le cas de l'Espagne, les éducateurs entreprirent de copier l'original anglais, mais ils renforcèrent plus tard la stabilité de l'autorité en donnant un rôle substantiel aux " regards intermédiaires " des moniteurs généraux. Les deux développements retrouvent leur origine dans les notions dominantes de l'enseignement dans chaque contexte. Les différents sentiers de réception et d'interprétation de ce système hautement codifié démontrent l'existence de « cultures de disciplines » différentes.

Mots-clés : salle de classe, discipline, visibilité, autorité, Espagne, Allemagne.

\section{Introduction: Visibility in the Classroom and the Emergence of Modern Schooling}

$\mathrm{O}$

NE OF THE MOST ENDURING TRANSFORMATIONS of mass-schooling during the nineteenth century was the consolidation of a consistent pattern of teaching that was characterized by group instruction in graded schools. Group instruction is now considered a central feature of modern schooling, but was only implemented as the result of a long, disputed and demanding process of re-shaping pedagogical practices by imposing comprehensive and rational models of order on classrooms.

In early modern times, the mere fact that children attended elementary schools did not necessarily mean that effective schoolwork, understood both as providing elementary skills and moralizing populations, actually took place. In the second half of the eighteenth century in particular, enlightened critics observed that inherited models of teaching and learning were inadequate in guaranteeing a well-ordered daily life in classrooms. These complaints put into question the legitimacy of the "old" or "individual" teaching method, prevalent in many European elementary schools until the middle of the nineteenth century. Sporadically arranged interrogations and recitations supervised by the schoolmaster focused on the performance of each child, and they did not necessarily address the whole group of heterogeneous pupils. ${ }^{2}$ Although students were supposed to work steadily and under supervision, this device required that they remained passive and uncontrolled for most of their school time.

Overcoming this unsatisfactory state of affairs primarily entailed adopting comprehensive and calculated models of order, enabling pupils of different ages and levels of achievement to work at the same time in a continuous and systematic way. In this context, many proposals for reforming the old model of schooling emerged in Western Europe. Group teaching as we know it today, monitorial schooling, and a wide range of mixed systems of teaching offered many alternatives to counteract the passivity and much-lamented idleness of the students. Considering the large sizes of the mixed-age groups to be schooled, visibility of all children in the classroom became a key to making elementary schooling effective. The issue of extending surveillance was addressed in particular by all these organizational and pedagogical proposals. 
They have strongly shaped our image of modern schooling and promoted one of the major technological shifts in the history of education.

Disciplining and its focus on the visibility of bodies set forth a theoretical frame for understanding the visual aspect underlying the reshaping of very different institutional settings, including factories, hospitals, prisons and schools. ${ }^{3}$ Disciplining constituted a task that had to be achieved by means of visual arrangements; these have been designated "an order of light." 4 The architecture of institutions and the disposition of bodies and things became essential conditions for an experience of the ordered world that has been a part of the "hidden curriculum" of schools in recent centuries. ${ }^{5}$ These arrangements enabled the interplay of "gazes" characteristic of the modern classroom. By "gaze" I mean the active, searching, and projective aspects of seeing as an embodied social strategy rather than a mere process of perception. ${ }^{6}$ Modern subjectivities resulted from, among other sources, analytically ordered institutional experiences strongly marked by consciousness of one's own visibility. ${ }^{7}$

I wish to argue that the basic function of ordering modern institutions by imposing a general visibility of bodies and actions on them was by no means as homogeneous as much critical and postmodern scholarship would suggest. It is certainly ironic that Foucauldian theory, usually associated with the so-called "new cultural history", has so rarely been implemented in assessing the role of cultural differences in the constitution of "disciplined" modern institutions and forms of subjectivity. Reshaping institutions, making them "ordered", has repeatedly been equated with the spread of a very homogeneous work of disciplining, ignoring cultural differences between the respective settings. ${ }^{8}$ By contrast, I would like to point out that the process of disciplining subjectivities in daily life institutions utilized different techniques and arrangements and these culturally distinct preferences led to a variation in disciplining strategies. These differences were not mere miscellanea but they also affected very central aspects of the program of disciplining, such as the construction of visibility in classrooms, leading eventually to contoured "cultures of disciplining."

Here I will present variations of ordering classrooms along the lines of the visibility of bodies and actions in the discussions and practices related to one of the most sensational proposals of school ordering - the English monitorial system of education - in two different contexts in the first half of the nineteenth century: the German States and Spain. Searching for cultural differences in schooling requires the analysis of settings with different traditions and cultural conditions. Spain and the German States are not only very different in their religious and political history. At the beginning of the nineteenth century, they had also developed very different rapport with their own pedagogical traditions. Whereas Spain underwent a bitter process of political and educational modernization after 1812 and Spaniards discarded many aspects of the own educational heritage, the German States had witnessed an unprecedented increase of local educational initiatives based on their own religious and political traditions. In this sense, a comparison between Spain and Germany can show the different receptivity of foreign models of schooling by local forces. 
In the following, I will assess the transcontinental importance of the monitorial schools in the transition from old forms of "disorganized" teaching to the disciplinary reshaping of classrooms. After this, I will succinctly describe the paths by which the monitorial model was introduced and received in the contexts of both Spanish and German States and focus on their distinctive preferences regarding the issue of the necessary interplay of gazes in the classroom. At the end, I will trace back these differences to the use of children in monitorial schools as "teachers in miniature" on the one hand and on the other hand to the respective views of schools as social places in each context.

\section{The Transcontinental Spread of the Monitorial System of Education}

The dynamics of the expansion, adoption, and even decline of the monitorial system of education was a novelty in the history of diffusion of educational innovations. Practiced by Andrew Bell around 1790 in Madras (India) and by Joseph Lancaster from 1798 in London, their pioneer reports, published respectively in 1797 and $1803,{ }^{9}$ unleashed an unprecedented wave of didactical publishing and educational enthusiasm. Optimistic anthropological views of children and their educability together with a growing demand for mass schooling devices favored the new model. Monitorial teaching offered a promising solution to the problem of ordering classrooms by using students — also called "monitors" — as direct instructors of small groups of students.

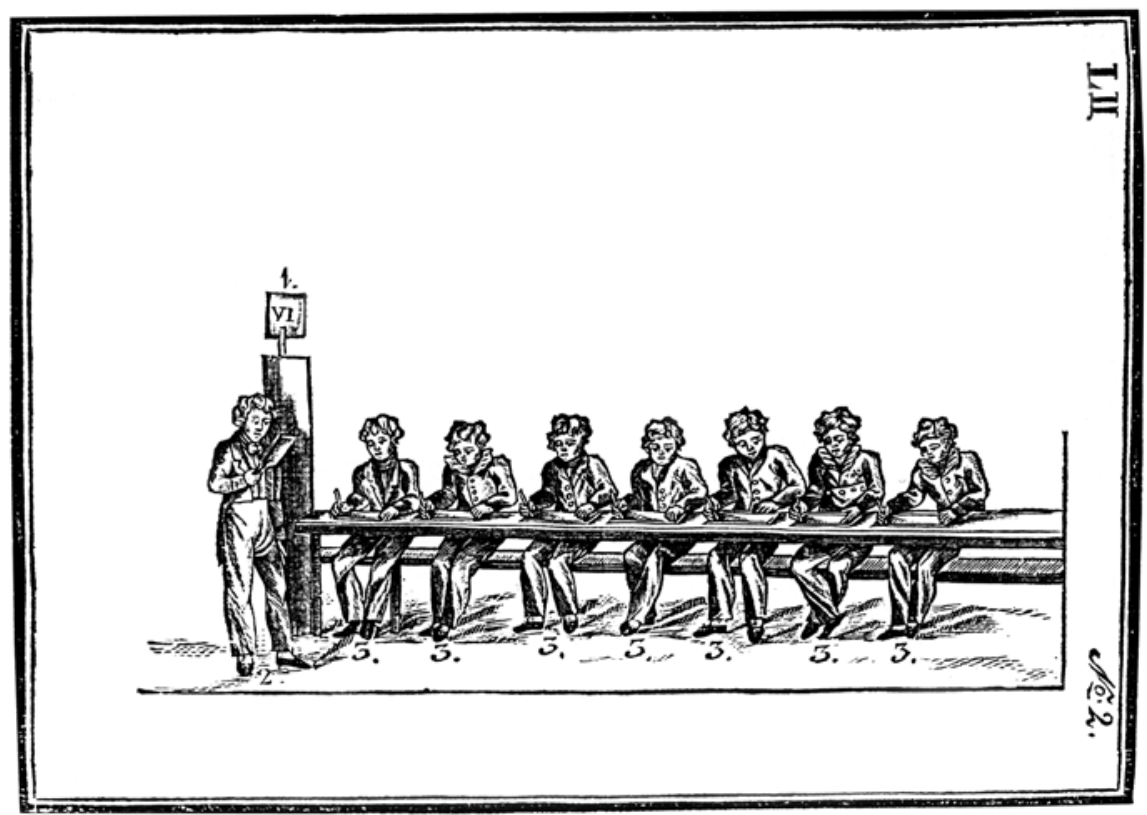

A writing class with a teaching monitor. Source: Joachim Catalá, Manual práctico o compendio del método de enseñanza mutua (Barcelona: Imprenta de José Torner, 1821), LII. 
Monitors were selected as "teachers" from among the best pupils. Lessons conducted by monitors were tightly planned, both in terms of the amount of time devoted to each group of students and in terms of the amount of content that had to be learned each time. Monitors were all linked by a strict chain of command in which their responsibilities were constantly changing - in some subjects they would act as monitors, in others simply as pupils. There were different kinds of monitors: "general monitors" commanded the so-called "monitors of order", who in turn controlled the "teaching monitors" (in charge of groups). The constant grouping and re-grouping of pupils according to their roles and the teaching content created a kind of choreography in the classroom; a choreography which was regulated by a series of standardized signs and commands supported by new didactical materials such as sand-desks for the learning of writing and tables of lessons for collective reading. It is noteworthy that this model of organization of teaching was highly recommended for both male and female schools. This idea of universal application beyond gender boundaries caused some anxieties in conservative circles, particularly in the Catholic world..$^{10}$

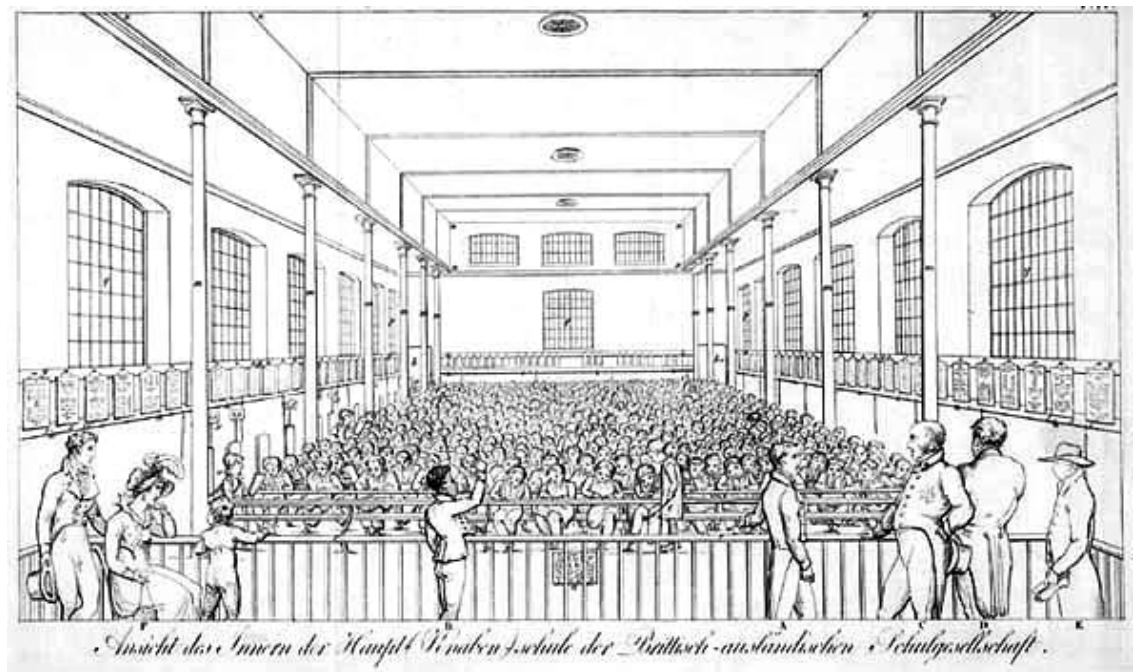

"View of the main male school of the British and Foreign School Society." Source: Joseph Hamel, Der gegenseitige Unterricht (Paris: Didot, 1818), Appendix, plate IV.

This systemic character of teaching and Lancaster's promise that up to a thousand children could be taught by only one schoolmaster impressed elites all over the world. Although other proposals for ordering elementary classrooms that had been set forth from the seventeenth century on also emphasized visibility and had tried to free the teacher's gaze from a consecutive occupation with only one pupil at a time, ${ }^{11}$ surveillance became a central issue in monitorial schooling. The functioning of this system required not only the teacher's sagacious coordination of the whole ensemble, but also the controlling gazes of all monitors, who had to compete in order to attain and retain their positions. In this economy of competition and emulation in a crowded 
setting, the visibility of bodies and actions, which was meant to lead to self-control and self-awareness, became particularly crucial for the functioning of the whole. ${ }^{12}$ Accordingly, the monitorial system of education constituted one central piece in the history of reshaping elementary teaching with disciplinary techniques in the nineteenth century.

Not least because of its promise of reshaping patterns of teaching using new forms of systematic interaction in the classroom, this system of teaching was not only widely implemented in Europe, but also in the five continents. ${ }^{13}$ Of course, whereas the appropriation of fundamental features of monitorial schooling always stressed the representation of an exact and rational order, the meanings attached to this exactness and rationality varied strongly across the different settings. I will present briefly the "German" and Spanish paths of reception in order to assess dissimilarities within Western Europe.

\section{The Monitorial System in the German States and Spain}

Despite all cultural, social and religious differences between the German States and Spain, both political settings bore some resemblances to each other. German and Spanish Liberal forces intended to establish a constitutional monarchy, and they found decided opposition in restorative groups. ${ }^{14}$ Enlightened and liberal efforts were successively successful in Spain (1812) — with a much-admired and disputed constitutional charter - in some central German states such as Bavaria and Württemberg (1818-1820), in Prussia (1848) and finally in Denmark (1849), which governed the German principalities of Schleswig and Holstein. ${ }^{15}$

If the political framing of the reception of the monitorial system did not lead to substantial variations of meaning and interpretation, educational trajectories did. The German States in particular had witnessed a real flood of educational and pedagogical literature from the last third of the eighteenth century on. Under the influence of pietism, ${ }^{16}$ the struggle for an ordered classroom became of utmost importance, reached a growing audience, ${ }^{17}$ and finally led to the establishment of institutions for teacher education in most of the States. ${ }^{18}$ The refinement of didactical discussion in the German States was unique at this time. Educational knowledge expanded and diversified, even reaching the highest spheres of systematic knowledge. This was the case for the first chair for education worldwide, held by Christian Trapp (1745-1818) in Halle in $1779,{ }^{19}$ or for Kant's lessons on education (1724-1804) in Königsberg. ${ }^{20}$ In addition, numerous publications, magazines, and educational journals supported the dynamics of educational discussion and controversy.

Germans and Austrians were possibly the first to ban the old structure of individual interrogation and recitation from elementary classrooms. At the beginning of the nineteenth century group teaching was increasing and in the middle of the century there were no traces of individual instruction. Germans had found a first solution in pure group teaching for the imperative of institutional ordering, when the monitorial system emerged. Consequently, the very translations of Bell's and Lancaster's seminal books into German included a great deal of criticism of certain principles and 
features of the method. ${ }^{21}$ Nonetheless, the impressive quantity of literature discussing the monitorial method between 1808 and 1850 displayed both the anxiety Germans felt because of the challenge of the new system and the demographic pressure in these decades, which consistently led to larger elementary classrooms.

Although German educational elites eschewed the promises of monitorial schooling, it is interesting to note that their bastions, the seminaries for teacher education, became one of the most significant places of experimentation with the new device. In many small cities in Prussia, Württemberg, and Hesse, experimental classes practicing monitorial techniques and the interest of the states - above all, Prussia, Saxony and Württemberg - in this system of teaching remained a striking issue until the middle of the century. ${ }^{22}$ But it was in Schleswig and Holstein, two German-speaking principalities under Danish rule, where a variation of monitorial schooling marked the pedagogy of elementary schooling. ${ }^{23}$ Danish militaries interested in monitorial schooling for the reshaping of their own military schools had introduced the system in a few Danish common schools, and the official educational policy then favored its general expansion in all parts of the kingdom. With the Normal school at Eckernförde, established in 1820, Schleswig and Holstein experienced a forced change of techniques which consolidated a kind of mixed method. This German mixed system denied children the capacity of teaching their classmates, limiting the collaboration of monitors to moments of repetition and to practice exercises. A whole ideology of "real" teaching, which included notions of an insurmountable difference between the words and deeds of adults and of children, had the upper hand. ${ }^{24}$ Aside from numerous, but only locally relevant experiments with monitorial techniques in cities such as Königsberg, Magdeburg, and Aschersleben, the model of monitorial schooling, in its "mixed version", spread consistently only in Schleswig and Holstein..$^{25}$

For one to take a look at Spain at this time entails dealing with the European periphery, even in educational issues. After two centuries of economic decline and cultural decay, enlightened efforts to modernize the country gained ground between 1770 and $1800 .{ }^{26}$ Modernizing circles organized in economic societies (Sociedades Económicas de Amigos del País) preached utilitarian notions of productive work, rationalization of agriculture, and the struggle against superstition and ignorance. ${ }^{27}$ They also initiated many projects of vocational and elementary schooling. However, these social and cultural forces only represented a tiny minority of Spanish elites and found varying support among some Churchmen. Educational issues became an issue, but not a serious concern for the state. After the first attempt to create a "well-ordered" and homogeneous daily life in primary schools between 1790 and 1792, when Juan Rubio and other agents sent from Madrid introduced Rubio's well-known system of elementary teaching in some cities, ${ }^{28}$ the only noticeable innovation was the failed import of the Pestalozzian method between 1805 and 1808. ${ }^{29}$

Beyond these limited initiatives of the central state, the only generally acknowledged group in educational issues after the expulsion of the Jesuit Order in 1767 was that of the Piarists, an Order (established in 1617) working in elementary education with considerable success across southern Europe. The Piarists were pioneers of pedagogical standardization in the country, as their unified method for Castile 
from 1780 onwards displays. ${ }^{30}$ On the whole, individual teaching was still popular among elementary teachers. Educational and pedagogical discussions animated by enlightened circles only reached a section of urban teachers and did not bring about a rationalized form of teaching.

Both the absolutist government and the local economic societies, being the modernizing agents par excellence, imported monitorial schooling at the same time. Whereas the captain John Kearney, a Spaniard of Irish descent, was sent by a group of important Court personalities to England in order to learn about the system in the Normal School in London, ${ }^{31}$ the economic society of the harbor city of Cadiz followed its own plans for the establishment of a monitorial school. ${ }^{32}$ Kearney established a normal school at the court of Madrid with official protection, and shortly after the king authorized all economic societies to establish monitorial schools at their expense. ${ }^{33}$ Additional support for monitorial schooling came from liberal forces, which took power in 1820 , in order to spread literacy among the masses at low cost. ${ }^{34}$ This urgency stemmed from the Spanish constitution of 1812, which foresaw that illiterate male adults would be excluded from franchise after 1830. In the liberalradical period known as Trienio (1820-1823) monitorial schooling became closely associated with freemasonry and radical patriotic societies, which initiated many monitorial schools in some regions of the country. ${ }^{35}$

Absolutist repression after 1823 affected monitorial expansion and the general regulations for primary schools from 1825 made the method of the Piarist Order mandatory, which also foresaw the help of the older children. The political change towards constitutional monarchy after 1834 opened up new opportunities for the diffusion of monitorial schooling, but drafts were initially more numerous than realizations. Monitorial schooling, at least in its pure form, remained a marginal device in Spanish primary schools, and the old individual method disappeared only in the last decades of the nineteenth century. However, Spaniards appreciated the advantages of the monitorial system and integrated it with some features of group teaching in the so-called método mixto, which prevailed in Spanish elementary schools until the end of the century.

In both settings, shared concerns about the ordering of the institutions for the populace met local conditions of interpretation, specific notions of acceptable teaching, and different educational backgrounds. The function of rendering hundreds of children visible was one crucial field where these conceptions became effectual and were not only "ideas." The strategies of producing "visibility" in the classroom using the heavily codified monitorial system did not lead to a homogenization of practices; rather, it generated different approaches to control, surveillance and visibility.

\section{Visibility for Ordering (I): The German Experience}

The translations of Bell's and Lancaster's works into German, both published in 1808 , already contained comments on the topic of visibility for disciplining. The priest Friedrich Tilgenkamp, in the introduction to his translation of Bell's book, asserted that the new system represented a better model of discipline because it was 
about observing and controlling: "the morality of the students will be thoroughly observed, each mistake will be noticed, carefully recorded and censured by a special jury." ${ }^{36}$ Ludwig Natorp, a very influential school inspector engaged in teacher education and a translator of Lancaster's book, asserted that a real teacher - in contrast to the helpers and monitors — has to be an expert in "observation." 37

The problem was that in monitorial schooling and its variations the power of the gaze included teachers as well as monitors of all kinds and ages. Instead, Germans insisted that children were not able to teach and considered pedagogical authority as a rapport among unequal subjectivities. With regard to visibility, the Bavarian school inspector Johannes Baptist Grasser was more precise: The "schoolmaster's eye" has to be active, more than the eyes of the monitors or helpers. ${ }^{38}$ This was important because "a student could not learn anything from another student." ${ }^{39}$ This idea of the impossibility of teaching by children found eminent visual formulations: "How could a blind man show the way to another blind man?" 40

This rejection was not only an issue of interpretation. More than that, the preference for the gaze of the schoolmaster as a guarantee of teaching and control led to considerably different practices of monitorial schooling. In schools characterized as pure "Lancastrian", Germans were already practicing a mix of monitorial techniques combined with moments of direct teaching by the schoolmaster. A good description of this mix of adult's and children's gazes was provided by the monitorial school in the city of Augsburg (Bavaria). There, "the schoolmaster can keep an eye on the learning progress." Yet it was not sufficient to control helpers and the general arrangement of the school. The teacher had to actually attend the classes in order to directly observe the course of the exercises: "During the mutual instruction, he goes continuously from one class to another and he is able to notice every negligence or every mistake of the monitors." ${ }^{41}$

The teaching at the Normal School in Eckernförde (Schleswig) showed similar practices and displayed a very prominent case of great consequence for the principalities under Danish rule. Danish and German officials elaborated a set of practices combining direct group teaching and monitorial techniques entitled "mutual school arrangement" (wechselseitige Schuleinrichtung), which became paramount for furthering the discussion in Germany. In Eckernförde, children were often aware of the intervention of the schoolmaster. In his description of the Normal School in Eckernförde, Henning Dieckmann, a teacher from Brunsbüttel (Schleswig), asserted that "the scrupulous teacher tends to see everything." ${ }^{2} 2$ Johann Möller, a catechist from Altona, also attended the Normal School and reported that the "upper monitor always has to be close to the schoolteacher; both have to be on a platform higher than the floor in order to see all sections and classes." ${ }^{43}$ Visibility exceeded this general attention from the platform and included a shrewdly calculated intervention of the teacher's gaze. If the students committed an offence during the exercises under the supervision of the monitor, the monitor could give the teacher a warning sign or he could call him. The adult had to decide the punishment, because this was not a function of the monitors. ${ }^{44}$ The presence of the adult's gaze was then significant in many schools using the German mutual method. Johann Friedrich Dücker's description of 
a rural school in Holstein organized according to the mutual method also showed the tension between the whole school and the specific class both simultaneously demanding the force of the teacher's gaze. After having introduced a new student and given numerous instructions, "he directed his eyes to the children of the upper class and observed them for some seconds." He told a story from the Bible, and gave the class more exercises on the story. "Then he came down from the platform... he crossed through the lower class in order to have a look, he looked at the exercises of the small students, prized here and scolded there and then called 'wash slates!'." 45

The original idea of a pyramid of gazes - leading from the bottom level of the monitors through the middle level of the general monitors to the upper level of the teacher - was not prevalent. In his description of the Normal School in Eckernförde, the schoolmaster Lars Hansen, from Flensburg, described the central difference between the English monitorial system and the variation practiced in the school in terms of the dominance of a passive gaze in the former. In the Lancastrian system the teacher only had "to classify the students, to select the monitors and to adapt the contents." "Then he is only incumbent for the conduction of the whole, for the overall control... His participation during the teaching is not necessary at all: He may only see that when the others work. He is nothing more than a factory inspector, just as this whole arrangement is an evident imitation of English factories." ${ }^{46}$ Hansen's claim for a more active gaze by the teacher was opinio communis in the German discussion. Christian Roger, a regional well-known teacher in Esslingen (Württemberg), shared their view and recommended more changes in the classroom - such as the position of the tableaus - "to keep an eye on each student during the exercises." ${ }^{47}$ On the whole, a general distrust of children's gaze was prevalent. Clearly, the participation of children in the ordering of the class was necessary. In the words of the schoolmaster in Vollmerhausen (Rhineland), this concept of a division of work was a "relief." 48 Yet this concentration also had to be balanced by some moments in which the schoolmaster was observing other classes. In this sense, he recommended the return of the schoolmaster's gaze so as to reinforce the helpers' control.

Germans consistently insisted on limiting this division of work. Even teachers who accepted the positive aspects of children teaching their schoolmates were very cautious about visibility via the children's gaze. If a teacher used the help of the most advanced pupils in teaching and repeating too often, they believed, the disadvantageous aspects of this technique would have the upper hand. "The teaching (by children, XX) always has to be controlled by the teacher, so that he can intervene when disadvantages creep in." ${ }^{49}$ Another visitor to the Normal School in Eckernförde, the School Director Carl Baumfelder from Dresden (Saxony), described the role of the helpers skeptically: "Nobody will think that the helpers could represent the spirit of the teacher, but only his body; they should help only his eyes, his hands and his feet as best they can." 50

Germans preferred a gaze that was active in its controlling function, close to the children, and marked by the presence of adults. Supporters of the German version of monitorialism accepted the collaboration of students, but they insisted that direct contact between students and the adult teacher reinforced the general practices of 
control via the monitors. The general supervision of the whole scene of teaching was not enough; it had to be reinforced by the personal interventions of the adult. Teachers depicted as factory supervisors implied the idea of cautious intervention. The schoolmaster's gaze simply had to be more preventive and productive rather than a gaze focused on sanctions and punishment.

\section{Visibility for Ordering (II): The Spanish Experience}

Spain's first experiences of monitorial schooling were very close to those of the original English version. John Kearney's male, model school in Madrid was certainly not a variation of the schools in London, but rather a copy. ${ }^{51}$ The Spaniards, who showed interest in this system of teaching, embraced it enthusiastically, and their supplements only affected the religious instruction (now Catholic) and some technical issues such as the order of letters on the reading tables. The pyramidal structure of visibility attached to the system did not meet significant opposition in bourgeois and nobles' circles ${ }^{52}$ and its power of "avoiding distractions" was generally praised. ${ }^{53}$

Joaquín Catalá, a Catalonian priest who was very committed to the monitorial system, was very explicit in his support for the pyramidal and machine-like structure of seeing: "The presence of the teacher is not always necessary for instruction; but nonetheless their functions are also important in the continuous surveillance of the correctors." ${ }^{54}$ Consequently, the correctors (monitors) had the right to punish the students, and they did not need the presence or authorization of the teacher. ${ }^{55}$ Catalá trusted in the efficacy of the system, which worked almost automatically or, in theory at least, could work without the continuous presence of the teacher. Following this principle, Catalá and his followers installed many monitorial schools in Catalonia and also in the countryside. ${ }^{56}$

The monitorial school established by the economic society in Cadiz and the Normal School in Madrid, both exclusively male schools, were the best known of their time. Teachers came from the countryside and from Seville to the former in order to learn about the system in this pioneer school. It was organized along the lines of the French manual of Nyon, which followed Lancaster's instructions very closely. ${ }^{57}$ Consequently, this first school had its platform and its inclination geared towards better visibility of the students. ${ }^{58}$ On the whole, the first school in Cadiz - a second was opened in the 1820s and a school for girls was established in 1827 - applied the pyramidal structure of seeing and controlling, which partly renounced the omnipresent gaze of the adults. A visitor to the Normal School in Madrid detected the pyramidal structure of the controlling gazes and asserted that "the teacher can always see all children from his distant chair." ${ }^{59}$ It is possible that the first liberal parliamentary draft for primary schools in 1822 was thinking of this economy of the visual when it recommended the monitorial system "in all the aspects related to the particular disposition of each school, the economy of school time and its inner order." 60

In spite of the backlashes in the spread of the system during the adamant restorative years leading up to 1833 , a principled support to monitorial visibility remained. Not only the monitorial system, but also other systems of elementary teaching such as 
those of Mariano Vallejo and Domingo Bacas Rojo stressed imitation and emulation as basic mechanisms for a well-ordered classroom. ${ }^{61}$ Both imitation and emulation presupposed the existence of a field of mutual visibility among pupils and not only the visibility of students' bodies and actions from the position of the adult teacher. Laureano Figuerola, a Catalonian teacher, then inspector and at the end of the century one of the most famous liberal economists of the country, defended the use of monitors due to its compatibility with certain spontaneous features of childhood: "It is a continuous observation that the children are great imitators, they imitate their mates more easily than the persons of more advanced age." ${ }^{62}$ His criticism of the old system of individual instruction highlighted the absence of common field of visibility: "What kind of emulation dominates in a school governed in this manner, where no kind of comparisons can be established between the daily tasks?" ${ }^{63}$ Each child not only has to compare their former performance with their current one, but also the difference between themselves and their mates, in order to promote competition and progress. In this context, visibility among children had its own pedagogical purposes, and the intervention of the gaze of the adults was not as prominent as in Germany.

At the same time, Spaniards also reconsidered the role of the adult teacher in monitorial schooling. Closely in tune with related English developments, they varied monitorial teaching in order to give the adult teacher a more prominent, but at a later stage, limited role. The leading educationalist of this time and founder of the first school for teacher education in Madrid, the physician Pablo Montesino (17911849), insisted that monitors were mere delegates of the adult teacher, also in terms of the production of a controlling visibility. These "helpers" multiply the powers of the "teacher's eyes." ${ }^{64}$ His influential views helped shape the first general Spanish law for primary schools, issued in 1838. Having the teacher's desk on the platform "for keeping his eye continuously on the whole school" was universally recommended, irrespective of the method practiced in the school. ${ }^{65}$ Montesino intended at the same time to develop a form of visibility which had more active intermediary gazes than those in the traditional monitorial classroom, and recommended sending the general monitors to inspect "the semicircles, going continuously from one to the other when the children are reading." ${ }^{66}$ The founding generation of "professional" modern Spanish educational thought and practice, the so-called normalistas, whose leader was indisputably Montesino, mostly followed this pattern of order.

Visibility through architecture consequently surpassed that of the German platform. In the words of the normalista Figuerola: "the floor of slightly crowded schools has to form an inclination of one foot for each 24 feet of length. The most elevated part will be on the opposite side of the teacher's desk." ${ }^{37}$ The teacher had to have a platform (two or three feet), "in order to supervise the whole class from his seat." ${ }^{68}$ It is likely that these recommendations were adopted in the organization of the first common schools of Barcelona in 1841, because the local school commission repeatedly asked Figuerola for advice on how to organize them. He designed the new classrooms and calculated the costs of these arrangements. ${ }^{69} \mathrm{In}$ a classroom arrangement in which the teacher was not intervening continuously, the inclination of the floor, also available in the first monitorial school in Cadiz, had to guarantee the distant, but free gaze of the teacher. 
Although Spanish educationalists increasingly preferred a mixed model of monitorial schooling and group teaching, the prevalence of the former was still apparent. The draft of a manual of monitorial schooling for the town of Cazalla, near Seville, by the teacher Andrés del Pino, insisted on technically constructing the classroom with regard to the pyramidal structure of the gazes. It is noteworthy that the platform for the teacher now had to be spacious enough so that "the instructors [another Spanish name for monitors, MC] could give a lesson in front of the whole school (...)" ${ }^{70} \mathrm{He}$ also combined the gaze of the monitors with his own as a teacher in the exercises, when the correction of exercises by monitors and by the teacher proceeded simultaneously. ${ }^{71}$ Notably after 1850, many slight variations of the monitorial pyramidal structure were set forth and practiced in other cities such as Saragossa ${ }^{72}$ and San Sebastián, ${ }^{73}$ without entirely abandoning the central role played by the monitors' gazes.

Clearly, mutual control among children produced a number of concerns among Spaniards. Teachers in the city of Madrid, more sympathetic to old practices of teaching, denied that the presence of monitors could bring more light — the "light" of the observer - to relations between children. For them, this relation was a source of "shadows", where immoral habits could be spread among children. ${ }^{74}$ The teacher on his platform has to be so isolated, that "he sees and hears nothing." In all the establishments, "where the teacher does not see and does not hear, everything will be overlooked and vice and demoralization will necessarily grow, and this not only among the spoiled children..." 75 However, these voices were in a defensive position and the increasing number of teachers trained in the normal schools probably followed the variations conceived by Montesino, Figuerola and others.

On the whole, the Spanish experience recognized both a close imitation of the factory-like organization of visibility attached to the English original, and some variations on the pyramidal structure of the gazes leading to a reinforcement of the teacher's authority. Controlling was not an exclusive business of the adults, but the gaze of the helpers had to become accustomed to order and authority. The increasing emphasis on the intermediary gazes of the general monitors, and the group lessons carried out by monitors in front of the whole school in del Pino's proposals indicated the increasing role of adult influence without discarding the role of monitors' gazes. This was accomplished by means of a stronger presence of those monitors with a closer relation to the teacher, the general monitors, or in situations where adults' and children's gazes intertwined in order to guarantee an ordered interaction. Spaniards were reluctant to accept the instability suggested by the many intermediary gazes, yet at the same time they did not consider these gazes to be intrinsically worthless, as in the German discussion. This view eventually led to a more stable "play of gazes." Up until the organization of the first graded schools from 1898 on, this strategy of visibility, which relied on monitorial techniques, was still heavily in use.

\section{Explaining Differences: Patterns of Educational Knowledge}

The different ways in which the function of visibility was implemented in ordering the elementary classroom in both contexts shows that the perceived necessity of a 
specific social function, such as the ordering of classrooms, only opens up a field of possibilities and does not predict "outcomes" in detail. Indeed, the crucial function of rendering bodies and actions visible in elementary classrooms could be performed in many different ways. In this field of possibilities, actors dealt with new proposals to comprehensively reshape daily life in schools within their cultural horizons and, in so doing, they examined and reproduced their own educational and pedagogical traditions.

In the German case, both the wide rejection of the pure model of monitorial schooling and the variations practiced in some schools were encapsulated by a central idea of eighteenth century German educational discourse: Children are not able to teach other children. Although German educators had traditionally practiced forms of monitorial teaching in both Lutheran and Catholic territories, ${ }^{76}$ it was the preacher August Herrmann Francke (1663-1727), who drew a dividing line between teaching and learning. In his program, education, conceived as a work of spiritual rebirth, could not be carried out by children, who were considered to be sinful by nature. ${ }^{77}$ Deep mistrust of interaction between children together with the modeling of teaching along the lines of preaching led to a consistent discourse and to a set of techniques in which teaching was unmistakably equated with the work of a pious adult. ${ }^{78}$ His followers spread this model of group teaching and tolerated the fact that group teaching in crowded elementary schools was only possible if the teacher instructed each class or group separately, leaving the other classes in "silent seating" or "silent work." The adoption of this model by the Abbot Johan Ignaz Felbiger (1724-1788) in Silesia was the first step towards making this model acceptable for all denominations. $^{79}$ Such a blatant propagation of Pietistic techniques in Catholic regions is not so surprising if we take into account the fact that Francke himself had been heavily influenced by the educational discourse of French Jansenism. ${ }^{80}$

This view of teaching as being part of a broader holy work pervaded German educational thinking and consistently excluded the assistance of children in teaching. ${ }^{81}$ The gaze of the adult became the dominating source of order, not only in moments of direct class teaching but also in moments of punishment, and in the dynamics of control in the classrooms. Accordingly, the crucial production of visibility could by no means be entirely delegated to children. Even in those regions in which monitorial schooling was somewhat accepted, local practices displayed this deep mistrust. A rejection of the pyramidal structure of gazes reflected a fundamental rejection of children as "teachers in miniature", reinforced by both liberal and conservative German pedagogy throughout the nineteenth century. At the same time, the prevalence of the adult's gaze, even in schools practicing variations of monitorial schooling, carried forward the deep-rooted idea that schooling, a holy work still under the supervision of churchmen, required its own model of moralizing visibility. From this viewpoint, the form of visibility displayed in factories and the military represented only a "mechanical" order of no educational value. By contrast, "educational" visibility displayed a scene of "closer gazes", in which the presence of the adults defined the proximity. Evidently, the pyramidal structure of gazes did not comply with this pattern of meaning. 
Considering the fact that Spanish elementary schools had no convincing proposal for how to order elementary schools in the eighteenth century, it is hardly surprising that monitorial schooling was received so enthusiastically. All relevant educational agents of the eighteenth century - Piarists, Jesuits and the teachers organized by Juan Rubio in Madrid — knew some form of monitorial teaching. ${ }^{82}$ Unlike German patterns of educational meaning, the sharp division between teaching and learning was not perceived as being crucial in defining the educational value of a certain technique. In addition, the clear popularity of sensualistic theories of knowledge among Spanish elites facilitated the acceptance of monitorial schooling, since this "machine" of teaching guaranteed a huge number of repetitions and exercises. ${ }^{83}$ In sensualistic theories, these were central mechanisms for the forming of mental representations and for the transmission of knowledge. The general order of these exercises and repetitions under the general supervision of the adult teacher was widely accepted at first as a model of order.

Even when Spaniards varied the model of pyramidal surveillance and tried to generate situations in which the adult's "closer" gaze played a role, they principally addressed the issue of the instability of this structure of visibility. Numerous proposals consequently recommended many forms of diminishing rotation and instability of monitors' positions, fixing the gaze of authority to certain children such as the general monitors. Analogous to Germany, where decisions regarding the construction of visibility partly reflected views of the legitimacy of teaching children, Spanish variations accepted the pyramidal structure of visibility. Unlike Germany, the work of teaching was not considered to be a holy one, but rather a kind of mechanical art of moral significance. In this sense, changes in the construction of visibility in Spanish monitorial classrooms tended to display uneasiness with the frequent changes of position in the classroom which the Spaniards met with models containing ordered or limited rotation of positions, ${ }^{84}$ rather than the pyramidal structure of the gazes as such. Disparaging references to factories and the military and their "distant" forms of visibility are not present in the Spanish discussion, and the few allusions there were to these social situations tended instead to emphasize the positive view of these social practices.

\section{Concluding Words: Cultures of Classroom Visibility}

A gaze is not only perception. A gaze is active: it searches, identifies and locates. The gaze, as used in the old metaphors of early modern times, was a kind of light given to the confusion of the world. In a pedagogical situation, which included up to 400 students, the task of exercising authority via the eye was of eminent significance. Although all drafts and practices related to the monitorial system of education stemmed from the very explicit strategy of making the behavior of the students visible, the resources and meanings attached to this general idea were quite different in both examined contexts.

As Germans highlighted, visibility in schools was not the same as visibility in factories. The explicit task of forming subjectivities attached to schools is quite different from the disciplinarian effects of working in factories, because disciplined behavior 
there is rather a (welcome) by-product of daily life. In schools, where the focus was on the production of disciplined behavior rather than the random visibility of a workplace, the function of shaping subjectivities led to models of seeing that were decisively "closer" and more "constant." In the case of Spain, educational reformers eschewed the frequent changes in the structure of authority associated to the task of monitors. Although they accepted the more "distant" and "randomized" gaze of the adult teacher, they considered visibility as being better guaranteed by the intermediate gazes of the general monitors and by a stable staff of teaching monitors.

Both Spaniards and Germans sought order in the classrooms and achieved it by making didactical work more systematic, and by reinforcing control and the visibility of the students' bodies and actions. Even this perceived purpose of schooling common to both contexts underwent cultural notions elaborated by the elites about acceptable techniques or producing order. The different responses to the shared problem of making students visible and controllable were by no means a product of ethnocultural differences. Since elementary schooling at that time had become a field of rational intervention shaped by experts, the responses briefly presented in this essay were closely related to knowledge traditions acceptable to the respective elites. It is in this sense that educational traditions became relevant, not as popular traditions of schooling, but rather as traditions of elaborated knowledge. Stemming from different dominant traditions in the German States and Spain, divergent notions of childhood, learning and authority shaped decisions about achieving an orderly classroom through the visibility of bodies and actions.

The gaze, a central mechanism of disciplining and a transition between the "exteriority" of social relations and the "interiority" of the subjects, ${ }^{85}$ is by no means a natural phenomenon, but rather a cultural exercise, also in schools. The fact that the visibility of bodies and actions as a kind of "functional imperative" increasingly became a major feature of "well-ordered" Western institutions does not reveal much about the specific forms with which this general "function" was locally performed. Although Foucault wisely identified a common set of techniques with which to make all bodies and actions "visible" in "disciplinary institutions", both the increasing moralizing purposes of elementary schooling and the different cultural meanings of educational and pedagogical authority "filtered" these general purposes.

\section{Notes}

1. Research for this paper has been carried out within the scope of the project "National education and universal method: Dynamics of global diffusion and culture-specific forms of adoption of the Bell-Lancaster method in the 19th century“, founded by the German Agency for Research (Deutsche Forschungsgemeinschaft) and coordinated by Jürgen Schriewer and Marcelo Caruso (Berlin).

2. David Hamilton, Towards a Theory of Schooling (London, New York, Philadelphia: The Falmer Press, 1989); Gerhardt Petrat, Schulunterricht: Seine Sozialgeschichte in Deutschland 1750-1850 (München: Ehrenwirth, 1979). 
3. Michel Foucault, Discipline and Punish: The Birth of the Prison (Harmondsworth: Penguin Books, 1982); Niklas Luhmann, Das Erziehungssystem der Gesellschaft (Frankfurt/M.: Suhrkamp, 2002), 102-10.

4. Gilles Deleuze, Foucault (Frankfurt/M.: Suhrkamp, 1992), 49.

5. Upton Dell, "Lancasterian Schools, Republican Citizenship, and the Spatial Imagination in Early Nineteenth-Century America," Journal of the Society of Architectural Historians 55, no. 3 (1996); Peter E. Kurtze, “'a School House Well Arranged': Baltimore Public School Buildings on the Lancasterian Plan, 1829-1839," in Gender, Class, and Shelter. Perspectives in Vernacular Architecture, ed. Elizabeth Collins Cromley and Carter L. Hudgins (Knoxville, TN: The University of Tennessee Press, 1995).

6. Judith Butler, Theories in Subjection. The Psychic Life of Power (Stanford: Stanford University Press, 1997), 83-106; Georges Vigarello, "Du regard projeté au regard affecté," Communications, no. 75 (2004).

7. Ian Hunter, Rethinking the School. Subjectivity, Bureaucracy, Criticism (New York: St. Martin Press, 1994).

8. Anne Querrien, L'école mutuelle. Une pédagogiet trop efficace? (Paris: Le Seuil, 2005), Selçuk Aksin Somel, The Modernization of Public Education in the Ottoman Empire, 18391908. Islamization, Autocracy and Discipline (Leiden, Boston, Köln: Brill, 2001).

9. Andrew Bell, An Experiment in Education, Made at the Male Asylum of Madras (London: Printed for Cadell and Davies, 1797), Joseph Lancaster, Improvements in Education, as It Respects the Industrious Classes of the Community: Containing, a Short Account of Its Present State, Hints Towards Its Improvement, and a Detail of Some Practical Experiments Conducive to That End, 1st ed. (London: Printed and Sold by Darton and Harvey, J. Mathews, W. Hatchard, 1803).

10. For instance: Jean-Baptiste-Auguste Curet, De l'Enseignement mutuel, de son parallèle avec la méthode des écoles primaires et celles des Frères de la doctrine chrétienne, et de l'inconvenance de cette nouvelle méthode appliquée aux jeunes demoiselles (Béziers: H. Bousquet, 1819), 32.

11. Johann Amos Comenius, Große Didaktik. Die vollständige Kunst, alle Menschen alles zu lehren (Stuttgart: Klett-Cotta, 1993), 121. Original publication 1657.

12. David Hogan, "The Market Revolution and Disciplinary Power: Joseph Lancaster and the Psychology of the Early Classroom System," History of Education Quarterly 29, no. 3 (1989).

13. Stefan Hopman, "The Monitorial Movement and the Rise of Curriculum Administration: A Comparative View," in Case Studies in Curriculum Administration History, ed. Henning Haft and Stefan Hopman (London: The Falmer Press, 1990); Carl F. Kaestle, Joseph Lancaster and the Monitorial School Movement. A Documentary History (New York/London: Teachers College Press, 1973); Eugenia Roldán Vera and Thomas Schupp, "Bridges over the Atlantic: A Network Analysis of the Introduction of the Monitorial System of Education in Early-Independent Spanish America," in Nationalerziehung und Universalmethode. Frühe Formen schulorganisatorischer Globalisierung, ed. Jürgen Schriewer and Marcelo Caruso (Leipzig: Leipziger Universitätsverlag, 2005).

14. For Spain: Walther Bernecker, España entre tradición y modernidad. Política, economía, sociedad (siglos XIX y XX) (Madrid: Siglo XXI de España ed., 1999); Josep Fontana, La crisis del Antiguo Régimen, 1808-1833, 4. ed. (Barcelona: Grijalbo, 1992). For Germany: Manfred Botzenhart, Reform, Restauration, Krise. Deutschland 1789-1847 (Frankfurt am Main: Suhrkamp, 1985); Matthew Levinger, Enlightened Nationalism. The Transformation of Prussian Political Culture, 1806-1848 (Oxford: Oxford University Press, 2000). 
15. Thomas Nipperdey, Deutsche Geschichte 1800-1866. Bürgerwelt und starker Staat (München: Beck, 1994), 273; Irene Castells and Antonio Moliner, Crisis del Antiguo Régimen y revolución liberal en España (1789-1845) (Barcelona: Ariel, 2000), 40-41; Knud J. V. Jespersen, A History of Denmark (Hampshire, New York: Palgrave, 2004), 233-34.

16. Richard L. Gawthrop, Pietism and the Making of Eighteenth-Century Prussia (Cambridge (UK): Cambridge University Press, 1993).

17. This aspect is widely discussed in: Petrat, Schulunterricht, 133-86.

18. For Bavaria: Dieter Hüttner, Von der Normalschule zum Lehrerseminar. Die Entstehung der seminaristischen Lehrerbildung in Bayern (1770-1825) (München: UNI-Druck, 1982).; for Prussia:Michael Sauer, Volksschullehrerbildung in Preußen. Die Seminare und Präparandenanstalten vom 18. Jahrhundert bis zur Weimarer Republik (Köln, Wien: Böhlau, 1987).

19. Ernst Christian Trapp, Versuch einer Pädagogik (Berlin: Nicolai, 1780).

20. Immanuel Kant, "Vorlesung Über Pädagogik," in Ausgewählte Schriften zur Pädagogik und ihrer Begründung, ed. Hans-Hermann Groothoff (Paderborn: Ferdinand Schöningh, 1963). Original edition, 1803.

21. Andrew Bell, Schulmethodus. Ein Beitrag zur Verbesserung der Lehrmethode und Schuldisciplin in Niedern Volksschulen (Duisburg, Essen: Bei Bädeker und Kürzel, 1808), Joseph Lancaster, Ein einziger Schulmeister unter Tausend Kindern in einer Schule. Ein Beytrag zur Verbesserung der Lehrmethode und Schuldisciplin in Niedern Volksschulen, trans. B. C. L. Natorp (Duisburg, Essen: Bädecker und Kürzel, 1808).

22. "Die Königsberger städtischen Armenschulen," Pädagogische Blätter 1 (1842): 85-106; Kawerau, "Einige Worte über das Nachhelfen der Schüler unter einander," Der Erziehungs- und Schulrath 3 (1816): 17-34; "Schullehrerseminarium in Marienburg," Allgemeine Schulzeitung 4 (1827): 782-784.

23. See "Summarisk Extract", January 28, 1828 in: Staatsarchiv Schleswig/State Archives Schleswig, Abt. 18, N 100 H-I.

24. Justus Photophilus, Briefe uber die Lancaster-Methode im deutschen Sinne und Geiste, oder das Nachtheilige der deutschen Lancasterei (Leipzig: bei C. H. F. Hartmann, 1827), $20-32$.

25. For the Normal school in Eckenrförde, see: "Verschiedene von der Commission wegen der lancasterschen Unterrichtsmethode gemachte Anträge”, №148, 1823 (Staatsarchiv Schleswig/State Archives Schleswig, Abt. 65.2., Nº61 - I). For Magdeburg, see the documents in Stadtarchiv Magdeburg/City Archives of Magdeburg, Rep. 18(3) W2).

26. Henry Kamen, Golden Age Spain, 2nd ed. (Hampshire (UK), New York: Palgrave, 2005); Sara T. Nalle, "Literacy and Culture in Early Modern Castile," Past \& Present, no. 125 (1989).

27. Jean Sarraillh, La España ilustrada de la segunda mitad del siglo XVIIIi (FCE: Mexico \& Madrid, 1957).

28. See the documents in: Archivo Histórico Nacional (Madrid), Consejos 13162.

29. Rufino Blanco y Sánchez, Pestalozzi. Su vida y obras. Pestalozzi en España (Madrid: Imprenta de la Revista de Archivos, 1909).

30. Felipe Scío, Método uniforme para las escuelas de cartilla, deletrear, leer, escribir, aritmética, gramática castellana y ejercicios de doctrina cristiana como se practica por los padres de las Escuelas Pías (Madrid: Imprenta de Pedro Marín, 1780).

31. Archivo Histórico Nacional (Madrid), Consejos, 3597 (5). 
32. Rafael Jiménez Gámez, La Sociedad Económica gaditana y la educación en el siglo XIX (Jerez de la Frontera: Caja de Ahorros de Jerez, 1991).

33. Julio Ruiz Berrio, Política escolar de España en el siglo XIX (1808-1833) (Madrid: Consejo Superior de Investigaciones Científicas, 1970), 182-83.

34. For the Basque Provinces, see Jesús de Benito Pascual, La enseñanza de primeras letras en Gipuzkoa (1800-1825) (Bilbao: Diputación foral de Gipuzkoa, 1994); for Mallorca, Bernat Sureda García, La formación del profesorado en Mallorca. Antecedentes y origen de la Escuela Normal (Palma de Mallorca: Universitat de Palma de Mallorca, 1984).

35. Alberto Gil Novales, Las Sociedades Patrióticas (1820-1823). Las libertades de expresión y de reunión en el origen de los partidos politicos, 2 vols., vol. 1 (Madrid: Tecnos, 1975), 322-24.

36. F. W. Tilgenkamp, "Vorerinnerung," in: Bell, Schulmethodus, V.

37. B. C. L. Natorp, Note 3 in Lancaster, Ein einziger Schulmeister unter Tausend Kindern, 225.

38. Johannes Baptist Graser, Der erste Kindes-Unterricht, die erste Kindes-Qual. Eine Kritik der bisher üblichen Leselehrmethoden und eine nöthige Beilage zu der Elementarschule fürs Leben (Baireuth, Hof: Granische Buchhandlung, 1819), 62.

39. Ibid., 67.

40. Photophilus, Briefe Über Die Lancaster-Methode, 32.

41. Both in: Franz Joseph Müller, Die Erziehung in Volksschulen (Kempten: Druck und Verlag von T. Dannheimer, 1823), 158.

42. Henning Diekmann, Briefe darstellend die wechselseitige Schuleinrichtung nach ihrem Bestehen in der Normalschule zu Eckernförde (Altona: Bei J. F. Hammerich, 1826), 58.

43. J. C. Möller, Ueber Anwendung der wechselseitigen Schuleinrichtung in Volksschulen unserer Herzogthümer (Altona: Bei J. F. Hammerich, 1826), VII.

44. Diekmann, Briefe darstellend die wechselseitige Schuleinrichtung, 58-59.

45. Johann Friedrich Dücker, "Die "wechselseitige Schuleinrichtung"," in Schülererinnerungen aus Schleswig-Holstein, ed. G. Rickers (Husum: Wachholtz, 1987), 62.

46. Quoted in: Hans W. Gondesen, "Die Normalschule mit wechselseitiger Schuleinrichtung," Jahrbuch für die Schleswigsche Geest 42 (1994): 106-07.

47. Roger, "Resultate bezüglich der — seit dem November 1842 in der KnabenElementarschule zu Esslingen angewendeten - wechselseitigen Schuleinrichtung," Die Volksschule IV (1844): 289-314, 292.

48. C. P. Mörchen, Versuch einer kurzen Beschreibung und praktischen Darstellung der wechselseitigen Schuleinrichtung oder gegenseitigen Einübung in der Elementarschule (Gummersbach: In Commission bei Friedrich Luyken, 1838), 66.

49. F. C. Anthes, "Ist es rathsam, die größeren Schüler zum Unterrichte der kleineren, resp. Schwächeren zu benutzen?”, Allgemeine Schulzeitung 20 (1843): 1177-1180, 1180.

50. Carl Friedrich Gotthelf Baumfelder, Die Eckernförder Elementarschuleinrichtung (Dresden: Ch. F. Grimmer'sche Buchhandlung, 1835), 23.

51. See Kearney's draft for a manual of the system: Archivo Histórico Nacional (Madrid), Consejos, 3597 (5). 
52. For the divergent opinion of some teachers, see José Díaz Manzanares, Nulidades de la enseñanza mutua por Lancaster comparada con los sistemas españoles (Madrid: Imprenta de D. Fermín Villalpando, 1821).

53. Pedro Ferrer y Casaus, Introduction to José M. Lancaster, Sistema ingles de instruccion, ó colección completa de las invenciones y mejoras puestas en práctica en las escuelas reales de Inglaterra, trans. Pedro Ferrer y Casaus (Madrid: En la Imprenta de la Calle de la Greda, 1818), VII.

54. Joachim Catalá, Manual práctico o compendio del método de enseñanza mutua (Barcelona: Imprenta de José Torner, 1821), 35.

55. Ibid., 36.

56. Alfredo Sáenz-Rico Urbina, La educación general en Cataluña durante el Trienio Constitucional (Barcelona: Universidad de Barcelona, 1973).

57. Real Sociedad Económica de Amigos del País de Cádiz, Manual práctico del método de mutua enseñanza para las escuelas de primeras letras (Cádiz: Imprenta de Hércules, 1818).

58. Exercicios de enseñanza mutua (Cádiz: Imprenta de Carreño, 1818), I.

59. Report by Ramón Chimioni to the economic society in Madrid, July 18, 1818. Archivo de la Sociedad Económica Matritense de Amigos del País (Madrid), 262/12.

60. Esposicion sobre el estado de la enseñanza pública hecha á las Cortes por la Direccion General de Estudios (Madrid: Imprenta de Alban y Cía., 1822), 7.

61. Domingo Bacas Roxo, Enseñanza universal de las primeras letras (Madrid: Imprenta de Don Eusebio Alvarez, 1832); José Mariano Vallejo, Instrucción práctica para enseñar á leer por el nuevo método contenido en la teoría de la lectura (Madrid: Imprenta de D. M. de Burgos, 1834).

62. Laureano Figuerola, Manual completo de enseñanza simultánea, mutua y mixta (Madrid: Imprenta de D. Antonio Reyes, 1841), 26.

63. Ibid., 23.

64. Pablo Montesino, Curso de educación. Métodos de enseñanza y pedagogía (Madrid: Ministerio de Educación y Ciencia, 1988), 198. His lesssons were delivered between 1841 and 1849 .

65. "Métodos de enseñanza - arreglo mecánico de las escuelas. Continuacion," Boletín Oficial de Instrucción Pública $\mathrm{N}^{\circ} 17$ (October 31, 1841): 259-264.

66. "Métodos de enseñanza. Enseñanza mútua. Continuación," Boletín Oficial de Instrucción Pública №25 (February 28, 1842): 144-150, 146.

67. Figuerola, Manual Completo, 30.

68. Ibid., 36.

69. See the plans for the Lancastrian schools of the city signed by Figuerola (undated, probably 1840) in Arxiu administrativo de Barcelona (Barcelona), Comisión de Gobierno, 2634.

70. Andrés del Pino, "Manual practico de Enseñanza mutua, por el cual, muy bien, se puede enseñar y gratuitamente a todos los niños, y costear los utensilios a los pobres de la Villa de Cazalla," approx. 1837, Box 6, Folder 3, 1-12, Blanco White family collection, University of Princeton, 4, art. 7. The lessons held by monitors were foreseen in art. 49, Ibid., 10. 
71. Ibid., 9, art. 45.

72. Valentín Zabala and Julián López Catalán, Sistema universal de enseñanza (Zaragoza: Imprenta de D. Calisto Ariño, 1860).

73. Reglamento para el gobierno y régimen interior de las escuelas públicas, elemental y superior de San Sebastián (San Sebastián: Imprenta de Ignacio Ramón Baroja, 1857).

74. Academia de profesores de primera educación, Informe de la Academia de Profesores de Primera Educación (Madrid: Imprenta de D. Hernando, 1838), 13.

75. Ibid., 21.

76. Karl Schrems, "Der "Modus Catechizandi" der katholischen Kirchenkatechese in Deutschland im 16. und 17. Jahrhundert," Verhandlungen des historischen Vereins für Oberpfalz und Regensburg 106 (1966): 237; Gerald Strauss, Luther's House of Learning: Indoctrination of the Young in the German Reformation (Baltimore: Johns Hopkins University Press, 1978), 173.

77. August Hermann Francke, "Kurzer und einfältiger Unterricht, Wie die Kinder zur wahren Glückseligkeit, und christlichen Klugheit anzuführen Sind," in Pädagogische Schriften (Osnabrück: Biblio-Verlag, 1966).

78. August Hermann Francke, "Ordnung Und Lehrart, Wie Selbige in denen zum Waisenhause gehörigen Schulen eingeführet Ist," in Pädagogische Schriften (Osnabrück: Biblio-Verlag, 1966).

79. James van Horn Melton, Absolutism and the Eighteenth-Century Origins of Compulsory Schooling in Prussia and Austria (Cambridge: Cambridge University Press, 1988), 175-84.

80. Fritz Osterwalder, “Theologische Konzepte von Erziehung. Das Verhältnis von Fénelon und Francke," in Das Kind in Pietismus und Aufklärung, ed. Josef N. Neumann and Udo Sträter (Tübingen: Max-Niemeyer-Verlag, 2000).

81. On the consistent rejection of "teaching monitors" in Germany, see Marcelo Caruso, "Locating Educational Authority: Teaching Monitors, Educational Meanings and the Importing of Pedagogical Models. Spain and the German States in the 19th Century," in Educational Policy Borrowing: Historical Perspectives, ed. David Phillips and Kimberley Ochs (Oxford (UK): Symposium books, 2004).

82. Vicente Faubell Zapata, Acción educativa de los Escolapios en España (1733-1845) (Madrid: Fundación Santa María, 1987); Juan Rubio, Prevenciones dirigidas a los maestros de primeras letras (Madrid: En la Imprenta Real, 1788).

83. Marcelo Caruso, "Wirksamkeit der Oberfläche. Anthropologien der Gewöhung oder des Subjekts? Deutsche und spanische Deutungen des Bell-Lancaster-Systems im 19. Jahrhundert," in Pädagogische Anthropologie - Mechanismus einer Praxis, ed. Heinz-Elmar Tenorth, Ulrike Mietzner, and Nicole Welter (Weinheim: Beltz, 2007).

84. For this point, see Caruso, "Locating Educational Authority," 72-76.

85. Anne Vincent Buffault, "Regards, égards, égarements dans la ville aux XVIIIe Et XIXe Siècles," Communications, no. 75 (2004). 


\section{References}

\section{Archival Sources}

Archivo de la Real Sociedad Económica Matritense de Amigos del País (Madrid)

Archivo Histórico Nacional (Madrid)

Arxiu administrativo de Barcelon (Barcelona)

Princeton University Special Collections, Blanco White Family Collection

Staatsarchiv Schleswig (Schleswig)

Stadtarchiv Magdeburg (Magdeburg)

\section{Periodicals}

Allgemeine Schulzeitung (Darmstadt)

Boletín Oficial de Instrucción Pública (Madrid)

Der Erziehungs- und Schulrath (Breslau)

Die Volksschule (Stuttgart)

Pädagogische Blätter (Königsberg)

\section{Published Sources}

Academia de profesores de primera educación. Informe de la Academia de Profesores de Primera Educación. Madrid: Imprenta de D. Hernando, 1838.

Bacas Roxo, Domingo. Enseñanza universal de las primeras letras. Madrid: Imprenta de Don Eusebio Alvarez, 1832.

Baumfelder, Carl Friedrich Gotthelf. Die Eckernförder Elementarschuleinrichtung. Dresden: Ch. F. Grimmer'sche Buchhandlung, 1835.

Bell, Andrew. An Experiment in Education, Made at the Male Asylum of Madras. London: Printed for Cadell and Davies, 1797.

- Schulmethodus. Duisburg, Essen: Bei Bädeker und Kürzel, 1808.

Catalá, Joachim. Manual práctico o compendio del método de enseñanza mutua. Barcelona: Imprenta de José Torner, 1821.

Comenius, Johann Amos. Große Didaktik. Die vollständige Kunst, alle Menschen alles zu lehren. Stuttgart: Klett-Cotta, 1992, or. publication 1657.

Curet, Jean-Baptiste-Auguste. De l'Enseignement mutuel, de son parallèle avec la méthode des écoles primaires et celles des Frères de la doctrine chrétienne, et de l'inconvenance de cette nouvelle méthode appliquée aux jeunes demoiselles. Béziers: H. Bousquet, 1819.

Díaz Manzanares, José. Nulidades de la enseñanza mutua por Lancaster comparada con los sistemas españoles. Madrid: Imprenta de D. Fermín Villalpando, 1821.

Diekmann, Henning. Briefe darstellend die wechselseitige Schuleinrichtung nach ihrem Bestehen in der Normalschule zu Eckernförde. Altona: Bei J. F. Hammerich, 1826.

Dücker, Johann Friedrich. "Die "wechselseitige Schuleinrichtung."” In Schülererinnerungen aus Schleswig-Holstein, edited by G. Rickers, 55-65. Husum: Wachholtz, 1987.

Esposicion sobre el estado de la enseñanza pública hecha á las Cortes por la Direccion General de Estudios. Madrid: Imprenta de Alban y Cía., 1822.

Exercicios de enseñanza mutua. Cádiz: Imprenta de Carreño, 1818.

Figuerola, Laureano. Manual completo de enseñanza simultánea, mutua y mixta. Madrid: Imprenta de D. Antonio Reyes, 1841.

Graser, Johannes Baptist. Der erste Kindes-Unterricht, die erste Kindes-Qual. Eine Kritik der bisher üblichen Leselehrmethoden und eine nöthige Beilage zu der Elementarschule fürs Leben. Baireuth, Hof: Granische Buchhandlung, 1819.

Lancaster, José M. Sistema ingles de instruccion, ó coleccion completa de las invenciones y mejoras puestas en práctica en las escuelas reales de Inglaterra. Translated by Pedro Ferrer y Casaus. Madrid: En la Imprenta de la Calle de la Greda, 1818.

Lancaster, Joseph. Ein einziger Schulmeister unter Tausend Kindern in einer Schule. Translated by B. C. L. Natorp. Duisburg, Essen: Bädecker und Kürzel, 1808. 
Improvements in Education, as It Respects the Industrious Classes of the Community: Containing, a Short Account of Its Present State, Hints Towards Its Improvement, and a Detail of Some Practical Experiments Conducive to That End. 1st ed. London: Printed and Sold by Darton and Harvey, J. Mathews, W. Hatchard, 1803.

Möller, J. C. Ueber Anwendung der wechselseitigen Schuleinrichtung in Volksschulen unserer Herzogthümer. Altona: Bei J. F. Hammerich, 1826.

Montesino, Pablo. Curso de educación. Métodos de enseñanza y pedagogía. Madrid: Ministerio de Educación y Ciencia, 1988. Original from 1841.

Mörchen, C. P. Versuch einer kurzen Beschreibung und praktischen Darstellung der wechselseitigen Schuleinrichtung oder gegenseitigen Einübung in der Elementarschule. Gummersbach: In Commission bei Friedrich Luyken, 1838.

Müller, Franz Joseph. Die Erziehung in Volksschulen. Kempten: Druck und Verlag von T. Dannheimer, 1823.

Photophilus, Justus. Briefe über die Lancaster-Methode im deutschen Sinne und Geiste, oder das Nachtheilige der deutschen Lancasterei. Leipzig: bei C. H. F. Hartmann, 1827.

Real Sociedad Económica de Amigos del País de Cádiz. Manual práctico del método de mutua enseñanza para las escuelas de primeras letras. Cádiz: Imprenta de Hércules, 1818.

Reglamento para el gobierno y régimen interior de las escuelas públicas, elemental y superior de San Sebastián. San Sebastián: Imprenta de Ignacio Ramón Baroja, 1857.

Rubio, Juan. Prevenciones dirigidas a los maestros de primeras letras. Madrid: En la Imprenta Real, 1788.

Scío, Felipe. Método uniforme para las escuelas de cartilla, deletrear, leer, escribir, aritmética, gramática castellana y ejercicios de doctrina cristiana como se practica por los padres de las Escuelas Pías. Madrid: Imprenta de Pedro Marín, 1780.

Trapp, Ernst Christian. Versuch einer Pädagogik. Berlin: Nicolai, 1780.

Vallejo, José Mariano. Instrucción práctica para enseñar á leer por el nuevo método contenido en la teoría de la lectura. Madrid: Imprenta de D. M. de Burgos, 1834.

\section{Literature}

Bernecker, Walther. España entre tradición y modernidad. Política, economía, sociedad (siglos XIX y XXx). Madrid: Siglo XXI de España ed., 1999.

Blanco y Sánchez, Rufino. Pestalozzi. Su vida y obras. Pestalozzi en España. Madrid: Imprenta de la Revista de Archivos, 1909.

Botzenhart, Manfred. Reform, Restauration, Krise. Deutschland 1789-1847. Frankfurt am Main: Suhrkamp, 1985.

Buffault, Anne Vincent. "Regards, égards, égarements dans la ville aux XVIIIe et XIXe siècles." Communications, no. 75 (2004): 39-56.

Butler, Judith. Theories in Subjection. The Psychic Life of Power. Stanford: Stanford University Press, 1997.

Caruso, Marcelo. "Locating Educational Authority: Teaching Monitors, Educational Meanings and the Importing of Pedagogical Models. Spain and the German States in the 19th Century." In Educational Policy Borrowing: Historical Perspectives, edited by David Phillips and Kimberley Ochs, Oxford (UK): Symposium books, 2004, 59-87. . "Wirksamkeit der Oberfläche. Anthropologien der Gewöhnung oder des Subjekts? Deutsche und spanische Deutungen des Bell-Lancaster-Systems im 19. Jahrhundert." In Pädagogische Anthropologie - Mechanismus Einer Praxis, edited by Heinz-Elmar Tenorth, Ulrike Mietzner and Nicole Welter, Weinheim: Beltz, 2007, 64-77.

Castells, Irene, and Antonio Moliner. Crisis del Antiguo Régimen y revolución liberal en España (1789-1845). Barcelona: Ariel, 2000.

de Benito Pascual, Jesús. La enseñanza de primeras letras en Gipuzkoa (1800-1825). Bilbao:

Diputación foral de Gipuzkoa, 1994.

Deleuze, Gilles. Foucault. Frankfurt/M.: Suhrkamp, 1992. 
Dell, Upton. "Lancasterian Schools, Republican Citizenship, and the Spatial Imagination in Early Nineteenth-Century America." Journal of the Society of Architectural Historians 55, no. 3 (1996): 238-53.

Faubell Zapata, Vicente. Acción educativa de los Escolapios en España (1733-1845). Madrid: Fundación Santa María, 1987.

Fontana, Josep. La crisis del Antiguo Régimen, 1808-1833. 4. ed. Barcelona: Grijalbo, 1992.

Foucault, Michel. Discipline and Punish: The Birth of the Prison. Harmondsworth: Penguin Books, 1982.

Francke, August Hermann. "Kurzer und einfältiger Unterricht, Wie die Kinder zur wahren Glückseligkeit, und christlichen Klugheit anzuführen sind.” In Pädagogische Schriften, 15-71. Osnabrück: Biblio-Verlag, 1966.

- "Ordnung und Lehrart, Wie Selbige in denen zum Waisenhause gehörigen Schulen eingeführet Ist.” In Pädagogische Schriften, Osnabrück: Biblio-Verlag, 1966, 107-203.

Gawthrop, Richard L. Pietism and the Making of Eighteenth-Century Prussia. Cambridge (UK): Cambridge University Press, 1993.

Gil Novales, Alberto. Las sociedades patrióticas (1820-1823). Las libertades de expresión y de reunión en el origen de los partidos politicos. 2 vols. Vol. 1. Madrid: Tecnos, 1975.

Gondesen, Hans W. "Die Normalschule mit wechselseitiger Schuleinrichtung." Jahrbuch für die Schleswigsche Geest 42 (1994): 91-116.

Hamilton, David. Towards a Theory of Schooling. London, New York, Philadelphia: The Falmer Press, 1989.

Hogan, David. "The Market Revolution and Disciplinary Power: Joseph Lancaster and the Psychology of the Early Classroom System.” History of Education Quarterly 29, no. 3 (1989): 381-417.

Hopman, Stefan. "The Monitorial Movement and the Rise of Curriculum Administration: A Comparative View." In Case Studies in Curriculum Administration History, edited by Henning Haft and Stefan Hopman, London: The Falmer Press, 1990, 13-30.

Hunter, Ian. Rethinking the School. Subjectivity, Bureaucracy, Criticism. New York: St. Martin Press, 1994.

Hüttner, Dieter. Von der Normalschule zum Lehrerseminar. Die Entstehung der seminaristischen Lehrerbildung in Bayern (1770-1825). München: UNI-Druck, 1982.

Jespersen, Knud J. V. A History of Denmark. Hampshire, New York: Palgrave, 2004.

Jiménez Gámez, Rafael. La Sociedad Económica gaditana y la educación en el siglo XIX. Jerez de la Frontera: Caja de Ahorros de Jerez, 1991.

Kaestle, Carl F. Joseph Lancaster and the Monitorial School Movement. A Documentary History. New York/London: Teachers College Press, 1973.

Kamen, Henry. Golden Age Spain. 2nd ed. Hampshire (UK), New York: Palgrave, 2005.

Kant, Immanuel. "Vorlesung über Pädagogik." In Ausgewählte Schriften zur Pädagogik und ihrer Begründung, edited by Hans-Hermann Groothoff, Paderborn: Ferdinand Schöningh, 1963, 7-59.

Kurtze, Peter E. “'a School House Well Arranged': Baltimore Public School Buildings on the Lancasterian Plan, 1829-1839." In Gender, Class, and Shelter. Perspectives in Vernacular Architecture, edited by Elizabeth Collins Cromley and Carter L. Hudgins, Knoxville, TN: The University of Tennessee Press, 1995, 70-77.

Levinger, Matthew. Enlightened Nationalism. The Transformation of Prussian Political Culture, 1806-1848. Oxford: Oxford University Press, 2000.

Luhmann, Niklas. Das Erziehungssystem der Gesellschaft. Frankfurt/M.: Suhrkamp, 2002.

Nalle, Sara T. "Literacy and Culture in Early Modern Castile." Past \& Present, no. 125 (1989): 65-96.

Nipperdey, Thomas. Deutsche Geschichte 1800-1866. Bürgerwelt und starker Staat. München: Beck, 1994. 
Osterwalder, Fritz. "Theologische Konzepte von Erziehung. Das Verhältnis von Fénelon und Francke." In Das Kind in Pietismus und Aufklärung, edited by Josef N. Neumann and Udo Sträter, Tübingen: Max-Niemeyer-Verlag, 2000, 79-94.

Petrat, Gerhardt. Schulunterricht: Seine Sozialgeschichte in Deutschland 1750-1850. München: Ehrenwirth, 1979.

Querrien, Anne. L'école mutuelle. Une pédagogie trop efficace? Paris: Le Seuil, 2005.

Roldán Vera, Eugenia, and Thomas Schupp. "Bridges over the Atlantic: A Network Analysis of the Introduction of the Monitorial System of Education in Early-Independent Spanish America." In Nationalerziehung und Universalmethode. Frühe Formen schulorganisatorischer Globalisierung, edited by Jürgen Schriewer and Marcelo Caruso, Leipzig: Leipziger Universitätsverlag, 2005, 58-93.

Ruiz Berrio, Julio. Política escolar de España en el Siglo XIX (1808-1833). Madrid: Consejo Superior de Investigaciones Científicas, 1970.

Sáenz-Rico Urbina, Alfredo. La educación general en Cataluña durante el Trienio Constitucional. Barcelona: Universidad de Barcelona, 1973.

Sarraillh, Jean. La España ilustrada de la segunda mitad del siglo XVIII. FCE: Mexico \& Madrid, 1957.

Sauer, Michael. Volksschullehrerbildung in Preußen. Die Seminare und Präparandenanstalten vom 18. Jahrhundert bis zur Weimarer Republik. Köln, Wien: Böhlau, 1987.

Schrems, Karl. "Der "Modus Catechizandi" der Katholischen Kirchenkatechese in Deutschland im 16. und 17. Jahrhundert." Verhandlungen des historischen Vereins für Oberpfalz und Regensburg 106 (1966): 219-41.

Somel, Selçuk Aksin. The Modernization of Public Education in the Ottoman Empire, 18391908. Islamization, Autocracy and Discipline. Leiden, Boston, Köln: Brill, 2001.

Strauss, Gerald. Luther's House of Learning: Indoctrination of the Young in the German Reformation. Baltimore: Johns Hopkins University Press, 1978.

Sureda García, Bernat. La formación del profesorado en Mallorca. Antecedentes y origen de la Escuela Normal. Palma de Mallorca: Universitat de Palma de Mallorca, 1984.

van Horn Melton, James. Absolutism and the Eighteenth-Century Origins of Compulsory Schooling in Prussia and Austria. Cambridge: Cambridge University Press, 1988.

Vigarello, Georges. "Du regard projeté au regard affecté." Communications, no. 75 (2004): 9-17.

Zabala, Valentín, and Julián López Catalán. Sistema universal de enseñanza. Zaragoza: Imprenta de D. Calisto Ariño, 1860. 